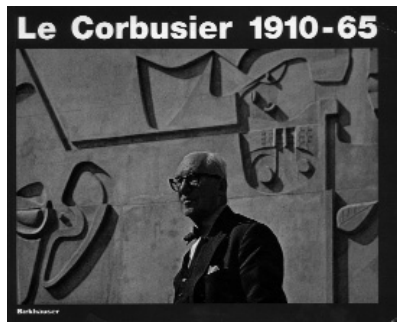

Willy Boesiger and Hans Girsberger

Le Corbusier 1910-65

Basel: Birkhäuser, 1999

Reviewed by Alessandra Capanna

One can conceive no better beginning to sketch the creative genius of Le Corbusier than the following sentences take from the laudatio accompanying the honorary doctorate degree from the faculty of jurisprudence of Cambridge University in June 1959:

...He holds philosophic views on his art: he believes with Pythagoras that number, and with Plato that geometry, underlies the harmony of the universe and the beauty of objects, and with Cicero that utility is the mother of dignity. He is also akin to Leonardo, in that he observes the principles of the engineer while applying to them the eye of a painter and sculptor, and for those who are seeking the famous "Divine Proportion", has proposed the standard he called "Modulor", based on the stature of man, or to be exact, a six-foot Englishman...

The recent republication of this book by Birkhäuser, the only volume of Le Corbusier's complete works, is an excellent vehicle for the divulgation and understanding of the mathematical spirit that runs through Le Corbusier's "patient research", more evident in some instances, more hidden in others. Most readers will already be familiar with the master from La Chaux-de-Fonds' study on the Modulor. Some pages in this book are dedicated to this "range of dimensions which makes the bad difficult and the good easy" (Albert Einstein). To complete the chapter, these pages are followed by other that examine the pictorial work, the sculptures and the woven wall hangings created by Le Corbusier. These are intended only to complete his architectural realizations, but more generally because his creative genius sank its roots in the ancient union of art and mathematics. This is an ideal and practical correspondence that is completely synthesized in the rude outlines in low-relief of the human figure that was engraved in the concrete of the Unités d'habitation. 
The present volume follows in large measure the impagination of the eight-volume edition, but the chronological catalog is subordinated to a subdivision in chapters that single out the great Corbusian themes: private homes, large-scale constructions, museums, sacred architecture and urban design. It should be considered, in any case, a basic text for the educational formation of architects. In terms of didactics, the study of Corbusier's works is an effective justification for the insistence on method in the practice of composition, even though this is somewhat less cultivated today. For those who are interested in the mathematic structures and in the geometric architectonics, this is a useful basic tool that above all makes it possible to compare the theory with the application. Beyond serving to verify the congruence of the method right through to the construction of a project, this is an exercise that allows us to understand that the objective of Le Corbusier in the identification and use of harmonic proportions was to show that he was conscious that an insistence on the initiatory character, on the magico-ritual aspect, of the golden number did not seem to be coherent with the scientific aspect of it, that which permitted the elaboration of a geometric grid in order to establish dimensional norms for each prefabricated habitable unit.

This book is also a useful instrument for approaching even those projects that are less wellknown, but are equally rich in the correct scientific applications of complex geometries, in large part conceptually derived from the studies undertaken for the Modulor. However, from this point of departure are derived a series of developments that are conceptually engaging not only as ulterior evolutions of mathematically structured compositions, but also from a typological point of view, as in the spiral and hyperbolic geometry.

The spiral is the figurative matrix for the museum based on continuous growth, and even if the first design ideas relative to this way of organizing a course of exhibit spaces can be traced to a period that precedes the studies for the Modulor, the intimate relationship between the laws that govern the growth of the logarithmic spiral, to which the form of the museum refers, and the value of the golden number, is well-known. The evolution of this compostional theme is examined in the beginning of the chapter on museums, where the first projects may be analyzed in an uninterrupted sequence, up to the realization of Ahmedabad and Tokyo. Hyperbolic geometry, which in Le Corbusier's work has been studied in relation to those works defined as "sonorous architecture", or rather as the response to technical-functional demands, led to the realization of volumes with original aesthetic characteristics. Because, as Le Corbusier affirms in the chapter dedicated to the mathematics in his book, The Modulor.

Mathematics is the majestic edifice imagined by man in order to comprehend the universe. There one encounters the absolute and infinite, what may be grasped and what may not be grasped. There walls are erected in front of which one may pass and repass without results; sometimes a door is found; one opens it and enters, and is in other places, there where the gods are found, there where lie the keys of the great systems. These door are those of miracles. Passing through one of these doors, the operating force is no longer man, but the contact with the universe. And before him occur and develop the fabulous series of limitless combinations. He is in the land of numbers.

First published in the NNJ online January 2000 


\section{The Reviewer}

Alessandra Capanna is an Italian architect living and working in Rome. She has taken her degree in Architecture at University of Rome "La Sapienza", from which she also received her Ph.D, discussing a thesis entitled "Strutture Matematiche della Composizione", concerning the logical paradigms in music and in architecture. She is the author of Le Corbusier. Padiglione Philips, Bruxelles, on the correspondance between hyperbolic paraboloid geometry and technical and acoustic needs, and its final and aesthetics consequences. She has published articles on mathematical principles both in music and in architecture such as "Una struttura matematica della composizione", remarking the idea of self-similarity in composition; "Musica e Architettura. Tra ispirazione e metodo", about three architectures by Steven Holl, Peter Cook and Daniel Libeskind; and "Iannis Xenakis. Combinazioni compositive senza limiti”, from a lecture given at the Dipartimento di Progettazione Architettonica e Urbana, University of Rome. She is presented a paper on Le Corbusier's Philips Pavilion at Nexus 2000. 